\title{
PENGARUH KEPEMIMPINAN, MOTIVASI, DAN KOMPENSASI TERHADAP KINERJA DOSEN
}

\author{
INFLUENCE OF LEADERSHIP, MOTIVATION, AND COMPENSATION TO \\ PERFORMANCE LECTURER
}

\section{Yudha Nata Saputra}

Sekolah Tinggi Teologi Cipanas

e-mail: yudhanata99@gmail.com

Naskah Diterima: 18 April 2019; Direvisi: 5 Agustus 2019; Disetujui: 11 Oktober 2019

\begin{abstract}
For improving the performance of lecturer then lecturer development management in tertiary institutions faculty are being important. There are many factors, both internal and external that affect the performance of the faculty, including the most factors are leadership, motivation and compensation, therefore this study intended to analyze the effect of three factors above either partially or simultaneously towards the performance of lecturers. In order to achieve the research objectives, the research method used is explanatory survey. The findings of the study found that there is a significant effect of leadership variable $\left(X_{I}\right)$ on the performance of lecturers $(Y)$ of $27.39 \%$, a significant effect of motivational variables $\left(X_{2}\right)$ on the performance of lecturers $(Y)$ of $26.69 \%$, a significant effect of the variable compensation $\left(X_{3}\right)$ on the performance of lecturers at $21.03 \%$ with three simultaneous effects by $73 \%$, which means the best perception of lecturers on the three variables above, the performance would be even better. Schools need to provide opportunities for lecturers to convey their wishes and hopes for the school. Schools need to reward lecturers for their works done. Compensation for lecturers should be given fairly. Schools need to develop the performance of appraisal system to improve the performance of lecturers.
\end{abstract}

Keywords: Leadership; Motivation; Compensation; Performance of lecturer

\begin{abstract}
Abstrak
Dalam rangka meningkatkan kinerja dosen maka manajemen pengembangan dosen di perguruan tinggi menjadi tumpuannya. Ada banyak faktor, baik internal maupun eksternal yang mempengaruhi kinerja dosen, diantaranya adalah faktor kepemimpinan, motivasi dan kompensasi. Penelitian ini bermaksud untuk menganalisa pengaruh dari ketiga faktor tersebut baik secara parsial maupun simultan terhadap kinerja dosen. Metode penelitian yang digunakan eksplanatory survey. Temuan studi menemukan bahwa terdapat pengaruh yang signifikan dari variabel kepemimpinan $\left(\mathrm{X}_{1}\right)$ terhadap kinerja dosen $(\mathrm{Y})$ sebesar $27,39 \%$, terdapat pengaruh yang signifikan dari variabel motivasi $\left(\mathrm{X}_{2}\right)$ terhadap kinerja dosen $(\mathrm{Y})$ sebesar 26,69\%, terdapat pengaruh yang signifikan dari variabel kompensasi $\left(\mathrm{X}_{3}\right)$ terhadap kinerja dosen sebesar 21,03\%, adapun pengaruh simultan ketiganya sebesar $73 \%$, yang berarti semakin baik persepsi dosen pada tiga variabel di atas, kinerjanya akan lebih baik. Untuk memperkuat posisi kepemimpinan, Ketua STT perlu memberikan kesempatan kepada dosen untuk menyampaikan keinginan-keinginan dan harapan mereka kepada institusi. Untuk meningkatkan motivasi dosen maka ketua perlu memberikan penghargaan kepada dosen atas usaha yang mereka lakukan dalam melaksanakan tugas-tugasnya. Dalam menetapkan kompensasi kepada dosen, hendaknya dilakukan dengan adil. Kemudian untuk meningkatkan kinerja dosen di STT, perlu disusun sistem penilaian kinerja dosen.
\end{abstract}

Kata Kunci: Kepemimpinan; Motivasi; Kompensasi; Kinerja dosen 


\section{PENDAHULUAN}

Menghadapi perubahan yang begitu cepat maka kebutuhan akan SDM (sumber daya manusia) yang bermutu menjadi suatu keniscayaan. Akibatnya kualitas kehidupan manusia sekarang dan ke depan akan banyak ditentukan oleh seberapa jauh manusia mampu mengolah dirinya dalam menghadapi perubahan. Rendahnya mutu SDM merupakan pokok persoalan yang menghambat kemajuan bangsa. Laporan United Nations Development Programme (UNDP) tentang Human Development Index (2016), masih menempatkan Indonesia $(0,689)$ di bawah Malaysia $(0,789)$ dan Thailand $(0,740)$, Indonesia baru berada di atas Filipina $(0,682)$ dan Vietnam $(0,683)$ (Jahan \& Jespersen, 2016).

Dalam rangka mengatasi rendahnya mutu SDM maka pendidikan menjadi ujung tombak utama. Tentunya proses pembelajaran yang bermutu, lulusan yang berprestasi, penelitian yang bermutu, hanya akan bisa terwujud jika dosen-dosennya memiliki kinerja yang tinggi. Penelitian Hakim mengungkapkan bahwa lingkungan kerja yang baik sangat mempengaruhi kinerja dosen (Hakim, 2011). Manik dan Syafrina, kompetensi dosen dalam melaksanakan tridarma perguruan tinggi memberikan pengaruh terhadap kinerja dosen (Manik \& Syafrina, 2018). Effendi, supervisi dekan memberikan pengaruh terhadap kinerja dosen (Effendi, 2013). Nursyamsi, kepemimpinan, pemberdayaan dan stress kerja berdampak kepada kinerja dosen (Nursyamsi, 2012). Permanasari, et.al., mengungkapkan bahwa profesionalisme, kompetensi berkontribusi terhadap kinerja dosen (Permanasari, Setyaningrum, \& Sundari, 2014). Shofwa, motivasi spiritual, kepemimpinan spiritual berpengaruh terhadap kinerja spiritual dosen (Shofwa, 2013). Nongkeng, et.al., pemberdayaan dosen dengan baik mampu meningkatkan kinerja dosen (Nongkeng, Armanu, Troena, \& Setiawan, 2012). Awaluddin, budaya organisasi, lingkungan kerja dan kepuasan kerja berpengaruh terhadap kinerja dosen (Awaluddin, 2016). Fauzan, dimensi struktural dan modal sosial mempengaruhi kinerja dosen demikian juga dengan gaya kepemimpinan transformasional yang memengaruhi peningkatan kinerja dosen (Fauzan, 2014). Pramudyo, motivasi, kompetensi dan kepemimpinan merupakan faktor yang perlu dipertimbangkan dalam menjelaskan kinerja dosen (Pramudyo, 2010). Meskipun penelitian terhadap kinerja dosen sudah banyak dilakukan, namun penelitian terhadap kinerja dosen pada perguruan tinggi keagamaan, khususnya perguruan tinggi keagamaan Kristen masih sangat sedikit sekali padahal dengan jumlah perguruan tinggi keagamaan Kristen saat ini yang berjumlah 364, merupakan hal yang penting untuk mendapatkan potret kinerja dosen sebagai ujung tombak peningkatan mutu pendidikan bagi perguruan tinggi keagamaan Kristen sehingga dapat diambil kebijakan yang tepat. Begitu juga dilihat dari sisi variabel yang diteliti dalam kinerja dosen, sampai saat ini belum diketahui pengaruh yang paling kuat di antara variabel Kepemimpinan, Motivasi dan Kompensasi yang diduga merupakan variabel paling berpengaruh terhadap Kinerja Dosen di lingkungan perguruan tinggi keagamaan Kristen.

Dengan jumlah perguruan tinggi agama Kristen sebanyak 364, dan jumlah dosen 7055 orang maka tentu sangat penting untuk segera dilakukan penelitian terhadap kinerja dosen di STT (Sekolah Tinggi Teologi)/PTAK (Perguruan Tinggi Agama Kristen). UU No. 14 Tahun 2005 Pasal 1 menyebutkan bahwa "Dosen adalah pendidik profesional dan ilmuwan dengan tugas utama mentransformasikan, mengembangkan, menyebarluaskan ilmu pengetahuan, teknologi, dan seni melalui pendidikan, penelitian, dan pengabdian pada masyarakat". Dengan tugas strategis yang diemban oleh dosen maka tidak salah jika dosen menjadi ujung tombak upaya peningkatan kualitas pendidikan suatu bangsa. Rencana Strategis Direktorat Jenderal Bimas Kristen mencatat dari 7055 dosen STT/PTAK baru 940 dosen yang sudah disertifikasi (Kementerian Agama, 2018), kendala sertifikasi ini salah satunya karena kualifikasi dosen yang belum memenuhi standar minimum S-2.

Dalam pembicaraan-pembicaraan dengan para pejabat di lingkungan Bimas Kristen Kementerian Agama RI baik melalui 
seminar maupun kunjungan ke Kantor Bimas Kristen Kementerian Agama RI di Jakarta, diketahui bahwa perhatian STT/PTAK untuk melibatkan dosennya dalam melakukan kegiatan penelitian sampai saat ini masih sangat rendah akibatnya jumlah guru besar yang dimiliki masih sangat jarang. Sementara itu berkenaan dengan upaya Kementerian Agama RI untuk melakukan sertifikasi kepada dosen-dosen sekolah tinggi teologi, juga sering terhambat karena selain belum memenuhi kualifikasi pendidikan (S-2) juga belum memiliki jabatan akademik sebagaimana yang dipersyaratkan.

Undang-undang RI No. 20 Tahun 2003 pasal 30 ayat 2 menyebutkan bahwa Pendidikan keagamaan berfungsi mempersiapkan peserta didik menjadi anggota masyarakat yang memahami dan mengamalkan nilai-nilai ajaran agamanya dan/atau menjadi ahli ilmu agama (Indonesia, 2003). Sementara berkenaan dengan tujuan pendidikan, UU RI No. 20 Tahun 2003 pasal 1 menyebutkan bahwa Pendidikan adalah usaha sadar dan terencana untuk mewujudkan suasana belajar dan proses pembelajaran agar peserta didik secara aktif mengembangkan potensi dirinya untuk memiliki kekuatan spiritual keagamaan, pengendalian diri, kepribadian, kecerdasan, akhlak mulia, serta keterampilan yang diperlukan dirinya, masyarakat, bangsa dan negara.

Bisa dikatakan bahwa salah satu dari antara sekian banyak tujuan pendidikan yang dilaksanakan di Indonesia adalah menghasilkan lulusan yang bukan hanya cerdas dan terampil tapi juga memiliki kekuatan spiritual kegamaan dan akhlak mulia yang diperlukan dirinya, masyarakat, bangsa dan negara. Dalam hal inilah pendidikan keagamaan memegang peranan penting, yaitu untuk menghasilkan lulusan yang bukan hanya memahami tapi juga mengamalkan ajaran agama sehingga tujuan pendidikan di atas dapat tercapai.

Namun persoalan mutu pendidikan, ternyata bukan hanya menjadi masalah perguruan tinggi umum saja tapi juga melanda perguruan tinggi keagamaan termasuk STT, dari 364 STT/PTAK baru 57 yang sudah terakreditasi institusinya, dari 57 tersebut, baru 6 yang terakreditasi B, sisanya C (Badan Akreditasi Nasional Perguruan Tinggi, 2019). Mutu pendidikan yang tidak berkualitas inilah yang disinyalir sebagai penyebab mengapa ada lulusan STT/PTAK yang menganggur.

Tabel 1. Kualifikasi dan profesionalisme dosen

\begin{tabular}{|c|c|c|c|c|c|c|c|c|c|}
\hline \multirow{3}{*}{ No. } & \multirow{3}{*}{ Perguruan tinggi } & \multicolumn{8}{|c|}{ Indikator kinerja kunci } \\
\hline & & \multicolumn{2}{|c|}{$\begin{array}{c}\text { Tingkat } \\
\text { pendidikan }\end{array}$} & \multicolumn{5}{|c|}{ Jabatan akademik } & \multirow{2}{*}{$\begin{array}{l}\text { Sertifikat } \\
\text { pendidik }\end{array}$} \\
\hline & & $\mathrm{S} 2$ & S3 & $\begin{array}{c}\text { Tidak } \\
\text { ada }\end{array}$ & $\begin{array}{l}\text { Asisten } \\
\text { ahli }\end{array}$ & Lektor & $\begin{array}{l}\text { Lektor } \\
\text { kepala }\end{array}$ & $\begin{array}{l}\text { Guru } \\
\text { besar }\end{array}$ & \\
\hline 1 & STT Kharisma & 14 & 4 & 7 & 9 & 2 & - & - & 9 \\
\hline 2 & STT Bandung & 12 & 9 & 9 & 4 & 8 & - & - & 6 \\
\hline 3 & STT INTI & 10 & 2 & 8 & 2 & 2 & - & - & 3 \\
\hline & Jumlah & 36 & 15 & 24 & 15 & 12 & _- & - & 18 \\
\hline
\end{tabular}

Kinerja dosen dalam perguruan tinggi, dapat diukur dari capaian tugas tridharma perguruan tinggi dosen, yang akan tercermin dari semakin banyak dosen yang menempati jabatan akademik dengan jenjang yang semakin tinggi. Tidak adanya dosen yang menempati jabatan akademik Lektor Kepala meskipun jika dilihat dari tingkat pendidikan sudah memenuhi menunjukkan bahwa kinerja dosen di STT belum optimal, kondisi yang sama juga bisa dilihat dari tidak adanya dosen yang menduduki jabatan Guru Besar meskipun dari sisi kualifikasi pendidikan sudah memenuhi.

Sementara, jumlah dosen yang belum memiliki jabatan akademik justru menempati jumlah paling banyak, meskipun jika dilihat dari kualifikasi pendidikan seharusnya sudah semua dosen memiliki jabatan akademik, hal ini menjadi bukti bahwa belum semua dosen memiliki kinerja yang tinggi, karena untuk mendapatkan jabatan akademik dosen, maka dosen harus sudah melaksanakan tridharma 
perguruan secara proporsional. Banyaknya jumlah dosen yang belum memiliki jabatan akademik berimbas kepada jumlah dosen yang memiliki sertifikat pendidik masih sedikit. Singkatnya, jika kinerja dosen-dosen di STT sudah optimal, yang ditandai dengan dilaksanakannya tugas tridharma perguruan tinggi secara menyeluruh, maka semua dosen sudah memiliki jabatan akademik, memiliki sertifikat pendidik dan adanya dosen yang sudah menduduki jabatan akademik Lektor Kepala dan Guru Besar.

Menyimak paparan di atas bisa disimpulkan bahwa kehadiran perguruan tinggi keagamaan seperti STT/PTAK sangat penting dalam rangka mencapai tujuan pendidikan nasional yang bukan hanya mengejar kesempurnaan kepada aspek materiel saja namun juga aspek spiritual agar tercipta manusia-manusia Indonesia yang bukan hanya cerdas dan terampil saja tapi juga berakhlak mulia. Dalam rangka melaksanakan perannya itu, mau tidak mau mutu pendidikan di STT/PTAK harus ditingkatkan agar bisa menghasilkan lulusan-lulusan yang berdampak bagi diri, masyarakat, bangsa dan negara. Tapi bagaimana mungkin STT bisa melaksanakan tugasnya itu, jika mereka tidak didukung dengan kehadiran dosen-dosen yang berkinerja tinggi. Oleh karena itu perlu segera dilakukan penelitian berkenaan dengan upaya untuk meningkatkan kinerja dosen di STT/PTAK.

Gibson, et.al, mengemukakan faktorfaktor yang mempengaruhi kinerja dosen di perguruan tinggi, meliputi faktor; individu, organisasi dan psikologis. Faktor individu, meliputi: kemampuan/ketrampilan, latar belakang (keluarga, tingkat sosial, pengalaman), dan demografi (umur, asal-usul dan jenis kelamin). Faktor organisasi, meliputi: sumber daya, kepemimpinan, imbalan, struktur, desain pekerjaan. Faktor psikologis, meliputi: mental/intelektual, persepsi, sikap, kepribadian, belajar, motivasi (Gibson, 2012). Berdasarkan paparan di atas maka faktor-faktor yang mempengaruhi kinerja dosen dapat diklasifikasikan menjadi dua yaitu faktor internal dan eksternal yang dapat digambarkan dalam Gambar 1.

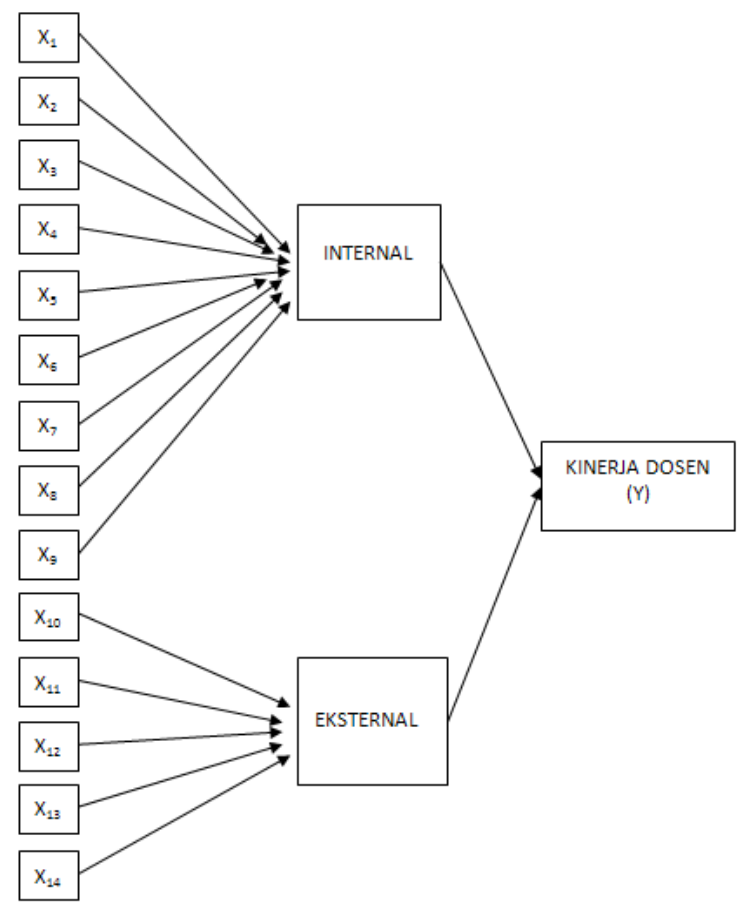

Gambar 1. Faktor-faktor yang mempengaruhi Kinerja Dosen. Keterangan: $X_{1}=$ Kemampuan, $X_{2}=$ Latar belakang, $X_{3}=$ Demografi, $X_{4}=$ Intelektual, $X_{5}=$ Persepsi, $X_{6}=$ Sikap, $X_{7}=$ Kepribadian, $\mathrm{X}_{8}=$ Pendidikan, $\mathrm{X}_{9}=$ Motivasi, $\mathrm{X}_{10}=$ Sumber daya, $\mathrm{X}_{11}=$ Kepemimpinan, $\mathrm{X}_{12}=$ Kompensasi, $\mathrm{X}_{13}=$ Struktur, $\mathrm{X}_{14}=$ Desain pekerjaan

Mengingat begitu banyaknya variabel yang mempengaruhi kinerja dosen dan keterbatasan peneliti maka penelitian ini, difokuskan kepada tiga variabel saja yaitu 
kepemimpinan, motivasi dan kompensasi. Kepemimpinan di perguruan tinggi memegang peranan penting dalam rangka pencapaian tujuan perguruan tinggi, dalam rangka mencapai tujuan ini maka pemimpin harus memiliki kemampuan untuk mengarahkan dosen agar mereka menunjukkan kinerja yang tinggi, dengan kata lain bisa disimpulkan bahwa keberhasilan perguruan tinggi dalam mencapai tujuannya sangat bergantung kepada kepemimpinan yang mampu mengarahkan dosen untuk mencapai kinerja yang tinggi, meskipun dalam hal ini kinerja perguruan tinggi berbeda tingkatannya dengan kinerja dosen, dan pencapaiannya dipengaruhi banyak faktor namun tidak dapat disangkal bahwa kinerja dosen cukup berperan dalam mencapai tujuan perguruan tinggi. Motivasi dipilih sebagai variabel kedua dalam penelitian ini, karena variabel ini merupakan variabel yang sering diungkapkan sebagai salah satu variabel kuat dalam menentukan kinerja individu dalam organisasi. Variabel kompensasi dipilih sebagai variabel ketiga, karena berperan penting dalam memenuhi kebutuhan dasar manusia sekaligus variabel ini bisa menjadi salah satu bentuk penghargaan terhadap dosen dan sering menjadi cermin keadilan, mengingat pentingnya hal ini maka variabel ini pun banyak diungkapkan. Teori Ekuitas menjelaskan bagaimana keadilan mempengaruhi kinerja individu, ketika orang merasakan ketidakadilan mereka berusaha untuk memulihkan keadilan. Salah satu cara yang dipakai individu untuk memulihkan keadilan adalah dengan mengubah tingkat kinerja, akibatnya meningkatkan persepsi keadilan berarti meningkatkan produktivitas dan kinerja. Keadilan sebagai salah satu aspek dalam pemberian kompensasi terhadap dosen berpengaruh terhadap kepuasan kerja dosen yang diyakini memiliki pengaruh terhadap kinerja dosen. Karena hal ini maka variabel kompensasi meskipun sifatnya sebatas memenuhi kebutuhan dasar dosen namun memiliki spektrum yang luas dalam mewujudkan kinerja dosen di perguruan tinggi.

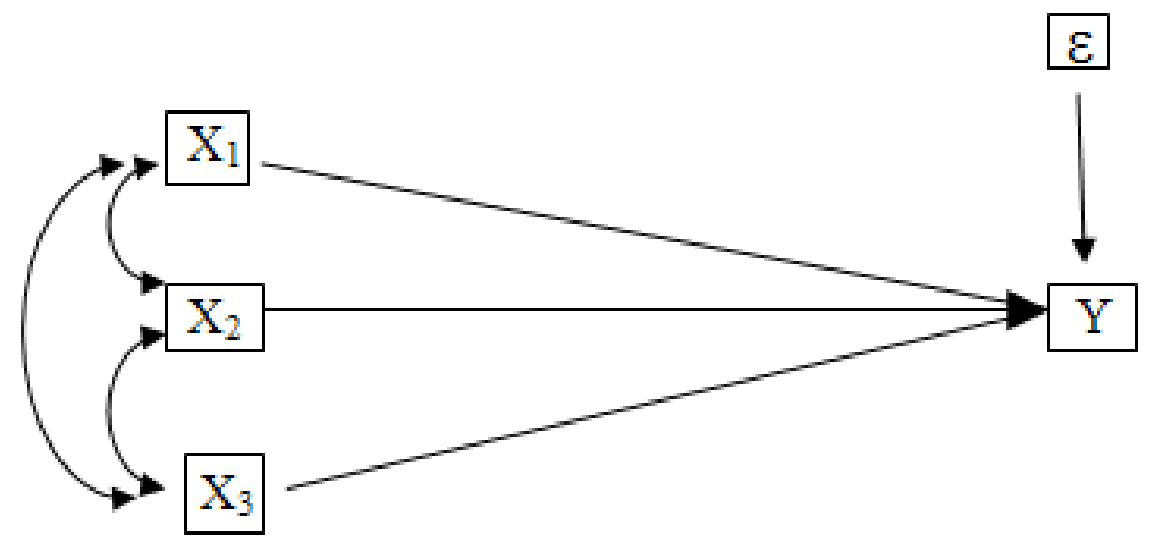

Gambar 2. Rumusan Masalah. Keterangan: $\mathrm{X}_{1}=$ Kepemimpinan, $\mathrm{X}_{2}=$ Motivasi, $\mathrm{X}_{3}=$ Kompensasi

Berdasarkan rumusan masalah di atas maka masalah dalam penelitian ini dinyatakan sebagai berikut: "Apakah terdapat pengaruh yang signifikan dari variabel kompensasi, kepemimpinan dan motivasi terhadap kinerja dosen ?". Penyataan masalah di atas diuraikan dalam pertanyaan penelitian sebagai berikut: 1) Apakah terdapat pengaruh yang signifikan dari variabel kepemimpinan terhadap variabel kinerja dosen?, 2) Apakah terdapat pengaruh yang signifikan dari variabel motivasi terhadap variabel kinerja dosen?, 3) Apakah terdapat pengaruh yang signifikan dari variabel kompensasi terhadap variabel kinerja dosen?, dan 4) Apakah terdapat pengaruh yang signifikan dari variabel kepemimpinan, variabel motivasi dan variabel kompensasi terhadap variabel kinerja dosen secara bersama-sama?.

Tujuan umum penelitian ini adalah untuk menganalisis pengaruh dari variabel kepemimpinan, variabel kompensasi, dan variabel motivasi terhadap kinerja dosen di STT Kharisma, STT Bandung dan STT INTI. Tujuan khusus penelitian ini dapat dijelaskan sebagai berikut: 1) Menganalisis pengaruh dari variabel kepemimpinan terhadap variabel kinerja dosen, 2) Menganalisis pengaruh 
variabel motivasi terhadap variabel kinerja dosen, 3) Menganalisis pengaruh variabel kompensasi terhadap variabel kinerja dosen, 4) Menganalisis pengaruh variabel kepemimpinan, variabel motivasi dan variabel kompensasi terhadap variabel kinerja dosen secara bersama-sama.

\section{Kerangka Konsep}

Kinerja dosen yang dimaksud dalam penelitian ini adalah hal-hal yang timbul dari kegiatan pendidikan \& pengajaran, penelitian dan pengabdian pada masyarakat (Indonesia, 2005). Dimensi-dimensi yang diukur dari penelitian ini, meliputi: (1) pendidikan dan pengajaran, dengan indikator: (a) sikap dosen dalam memotivasi mahasiswa, (b) menyusun buku teks sebagai bahan ajar, (c) membuat silabi pelajaran, (d) memberikan tugas terstruktur kepada mahasiswa, (e) interaksi dosen dengan mahasiswa dalam penguasaan bahan dan metodologi, (f) mengevaluasi hasil belajar; (2) penelitian, dengan indikator: (a) aplikasi hasil penelitian, (b) penyusunan rencana dan pelaksanaan penelitian, (c) pelaporan penelitian melalui jurnal, (d) melibatkan mahasiswa dalam penelitian, (e) publikasi hasil penelitian melalui koran, (f) frekuensi melakukan penelitian; (3) pengabdian kepada masyarakat, dengan indikator: (a) penyusunan rencana pengabdian kepada masyarakat dengan melibatkan mahasiswa, (b) kegiatan pengabdian kepada masyarakat dilaporkan pada publikasi ilmiah, (c) menawarkan kegiatan dengan mahasiswa, (d) mengaplikasikan hasil perkuliahan melalui kegiatan pengabdian kepada masyarakat, (e) frekuensi melakukan kegiatan.

Kepemimpinan yang dimaksud dalam penelitian ini mengacu kepada pendapat Fiedler, yaitu keberhasilan pemimpin dalam mempengaruhi kelompok (Fiedler, 1967). Dimensi dari variabel kepemimpinan ini menurut Fiedler meliputi : (1) hubungan pimpinan dengan anggota, dengan indikator: (a) taat kepada perintah atasan, (b) perilaku sesuai aturan, (c) berdisiplin; (2) kepercayaan kepada pemimpin, dengan indikator: (a) kejujuran pemimpin dalam melaksanakan tugas, (b) komitmen pemimpin dalam melaksanakan tugas, (c) kesediaan bawahan untuk menerima resiko dari pimpinan, (d) tindakan pemimpin untuk menepati janji; (3) rasa hormat anggota kepada pimpinan, dengan indikator: (a) perilaku bawahan dalam menghargai pemimpin, (b) pengakuan bawahan terhadap wewenang pemimpin, (c) kesediaan bawahan untuk menjaga nama baik pemimpin; (4) struktur tugas yaitu tingkat sejauh mana pekerjaan diprosedurkan, dengan indikator: (a) ketersediaan deskripsi tugas untuk setiap pekerjaan, (b) ketersediaan fasilitas untuk mengerjakan tugas, (c) pemahaman bawahan untuk melakukan pekerjaan yang ditugaskan; (5) kekuatan posisi pimpinan, dengan indikator: (a) pengaruh pimpinan terhadap perekrutan, (b) pengaruh pimpinan terhadap pemecatan, (c) pengaruh pimpinan terhadap disiplin bawahan, (d) pengaruh pimpinan terhadap kenaikan gaji, (e) pengaruh pimpinan terhadap promosi.

Motivasi yang dimaksud dalam penelitian ini mengacu kepada pendapat Gray, et.al (1984) sebagaimana dikutip oleh Winardi, yaitu sikap antusiasme dan persistensi, dalam hal melaksanakan kegiatan (Winardi, 2002). Adapun yang menjadi dimensinya (Sardiman, 2011), meliputi: (1) tekun mengerjakan tugas, dengan indikator: (a) mengerjakan tugas sampai selesai, (b) teliti dalam mengerjakan sesuatu, (c) serius dalam mengerjakan sesuatu, (d) memiliki keyakinan untuk bisa menyelesaikan; (2) ulet menghadapi masalah, dengan indikator: (a) keyakinan dalam menemukan jalan keluar untuk masalah yang dihadapi, (b) tidak lari dari masalah, (c) mampu menghadapi tekanan; (3) menunjukkan minat pada banyak hal, dengan indikator: (a) senang mencari tahu hal-hal baru, (b) senang mengamati perkembangan dunia, (c) memiliki rasa penasaran yang tinggi, (d) senang memikirkan sesuatu; (4) bekerja mandiri, dengan indikator: (a) tidak senang diganggu dalam mengerjakan sesuatu, (b) mampu mengambil keputusan sendiri, (c) mampu memikul tanggung jawab pekerjaan sendiri; (5) menyukai tantangan, dengan indikator: (a) mampu menarik pelajaran dari kesulitan, (b) tidak lari dari masalah, (c) suka bekerja keras; (6) memiliki keyakinan, dengan indikator: (a) mengetahui apa yang ia lakukan, (b) tidak mudah diombang-ambingkan oleh pendapat orang lain, (c) memiliki insting yang kuat. 
Kompensasi dalam penelitian ini adalah gaji yang diterima dosen setiap bulannya. Adapun yang menjadi dimensi-dimensinya (Moekijat, 1992), yaitu: (1) gaji harus memenuhi kebutuhan pokok minimum, dengan indikator: (a) tidak harus mencari penghasilan tambahan, (b) mencukupi untuk memenuhi kebutuhan sehari-hari, (c) ada penghasilan yang bisa disisihkan; (2) gaji diberikan secara adil, dengan indikator: (a) gaji yang diberikan sepadan dengan tugas yang diterima, (b) gaji yang diberikan sesuai dengan standar yang berlaku di tempat lain; (3) waktu pemberian gaji, dengan indikator ketepatan waktu dalam pembayaran gaji; (4) gaji yang diberikan mengikuti perkembangan harga pasar, dengan indikator: (a) kenaikan gaji secara berkala, (b) kenaikan gaji sesuai dengan yang diberikan di tempat lain; (5) sistem pembayaran gaji mudah dipahami, dengan indikator: (1) tersedia slip gaji yang memuat rincian gaji, (2) gaji yang diperoleh mudah dihitung sendiri; (6) perbedaan dalam tingkat gaji didasarkan atas evaluasi jabatan yang objektif, dengan indikator: (1) kenaikan gaji dilakukan secara objektif, (2) gaji yang diterima sesuai dengan jabatan yang diemban; (7) peninjauan terhadap struktur gaji, dengan indikator: (1) gaji disesuaikan dengan perubahan UMR, (2) pertimbangan terhadap situasi dan kondisi yang berubah.

Setiap penelitian ilmiah harus berorientasi dan berakhir pada kebenaran ilmiah. Untuk mendukung kebenaran tersebut diperlukan konstruksi teoretik dan pencarian bukti-bukti empirik. Kerja penelitian pada hakikatnya merupakan proses yang sistematik dan menggunakan metode tertentu guna memperoleh kebenaran yang dapat dipertanggungjawabkan. Sehubungan dengan itu, perlu disusun kerangka penelitian yang didalamnya memuat sudut pandang peneliti, proses penelitian, orientasi dan hasil akhir yang diharapkan dari penelitian. Secara ringkas, kerangka penelitian ini disajikan dalam Gambar 3.

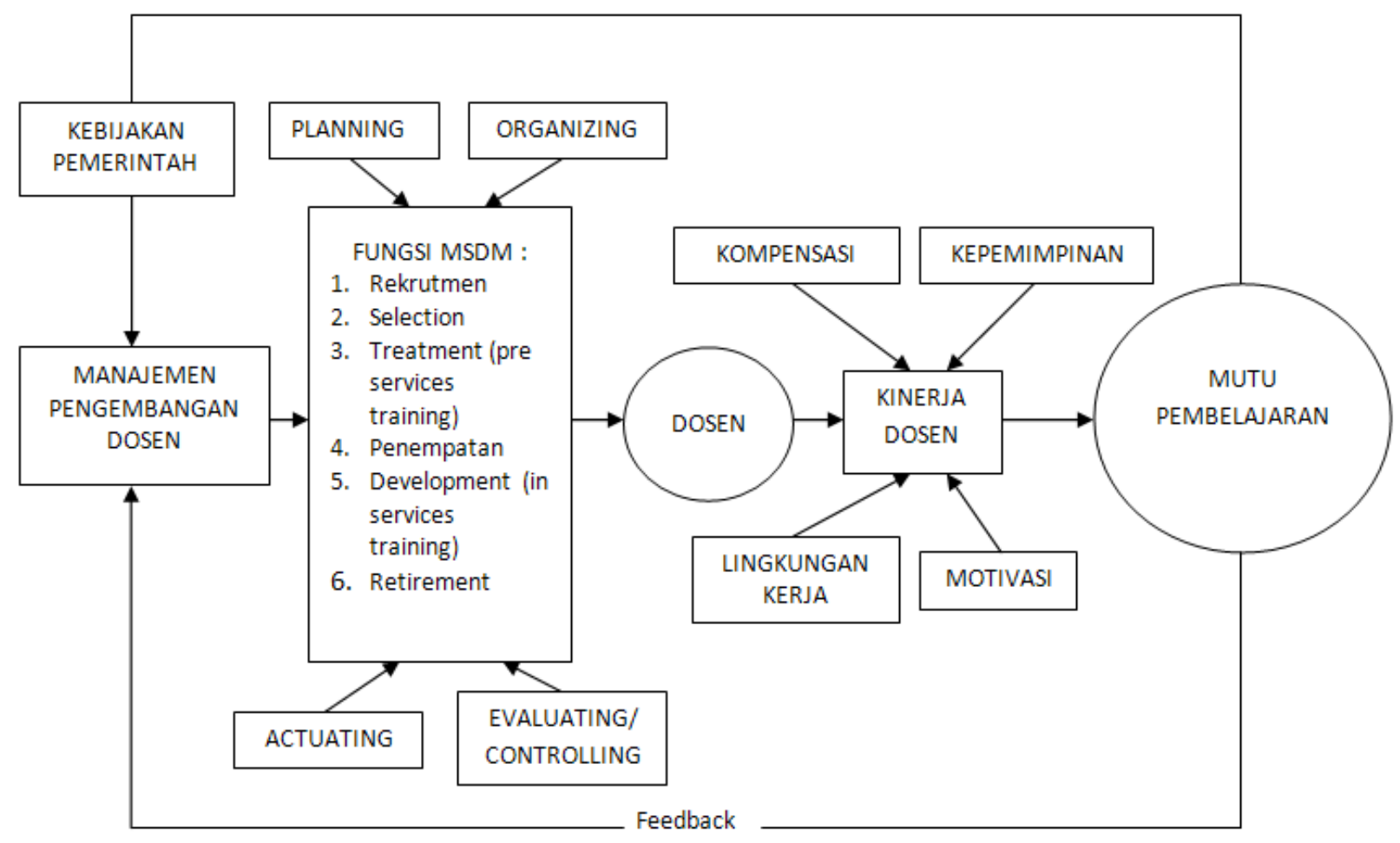

Gambar 3. Kerangka Penelitian

\section{METODE PENELITIAN}

Pendekatan yang digunakan dalam penelitian ini adalah menggunakan pendekatan kuantitatif, hal ini sesuai dengan tujuan dari penelitian ini yaitu untuk menganalisa pengaruh dari variabel kepemimpinan, variabel kompensasi, variabel motivasi terhadap variabel kinerja dosen. Adapun metode penelitian yang digunakan adalah eksplanatory survey karena penelitian ini diarahkan untuk menguji hipotesis. Sebagai konsekuensinya maka variabel-variabel penelitian perlu dioperasionalkan ke dalam indikator-indikator 
yang dapat diukur sehingga menggambarkan jenis data dan informasi yang diperlukan untuk menguji hipotesis tersebut. Teknik pengumpulan data yang digunakan adalah melalui skala penilaian sikap. Berdasarkan karakteristik data tersebut selanjutnya dirancang model uji statistik untuk menguji hipotesis yang dirumuskan.

\section{HASIL DAN PEMBAHASAN}

Data penelitian ini merupakan hasil jawaban responden dalam mengisi pertanyaan pada instrumen penelitian yang disebarkan. Pada analisis penelitian, diuraikan berdasarkan kepada operasionalisasi variabel penelitian. Data dikumpulkan dengan menggunakan alat ukur skala sikap yang telah diuji validitas dan reliabilitasnya. Deskripsi dan operasionalisasi konsep-konsep dalam instrumen penelitian ini dilakukan berdasarkan pengamatan terhadap gejala-gejala dilapangan. Dipaparkan dan diberikan penjelasan terhadap pernyataanpernyataan yang telah diklasifikasikan dalam kategori variabel secara deskriptif. Terdapat empat variabel dalam penelitian ini, yaitu variabel Kepemimpinan $\left(\mathrm{X}_{1}\right)$, Variabel Motivasi $\left(\mathrm{X}_{2}\right)$, Variabel Kompensasi $\left(\mathrm{X}_{3}\right)$, dan Variabel Kinerja Dosen (Y). Untuk mengetahui gambaran mengenai persepsi 39 Responden terhadap variabel Kepemimpinan (X) digunakan analisis deskriptif secara statistik.

Tabel 2. Distribusi frekuensi variabel kepemimpinan $\left(\mathrm{X}_{1}\right)$

\begin{tabular}{|c|c|c|c|}
\hline Alternatif jawaban & Frekuensi (f) & $\mathrm{f} \mathrm{X} \mathrm{b}$ & Presentase (\%) \\
\hline 5 & 174 & 870 & 22.31 \\
\hline 4 & 303 & 1212 & 38.85 \\
\hline 3 & 139 & 417 & 17.82 \\
\hline 2 & 105 & 210 & 13.46 \\
\hline 1 & 59 & 59 & 7.56 \\
\hline Jumlah & 780 & 2768 & 100 \\
\hline Skor & $=\sum(\mathrm{f} \mathrm{x} \mathrm{b)} / \mathrm{n}$ & \multicolumn{2}{|c|}{3.55} \\
\hline Klasifikasi & $=$ & \multicolumn{3}{|c|}{ Baik } \\
\hline
\end{tabular}

Pada skor kategori variabel Kepemimpinan menunjukan angka 3,55. Nilai ini berada pada rentang 3,41 hingga 4,20, hal ini mengklasifikasikan kategori baik pada variabel tersebut. Dengan demikian dapat

disimpulkan bahwa kepemimpinan sudah baik berdasarkan persepsi 39 orang dosen. Untuk mengetahui gambaran mengenai persepsi 39 Responden terhadap variabel Motivasi $\left(\mathrm{X}_{2}\right)$ digunakan analisis deskriptif secara statistik.

Tabel 3. Distribusi frekuensi variabel motivasi $\left(X_{2}\right)$

\begin{tabular}{|c|c|c|c|}
\hline Alternatif jawaban & Frekuensi (f) & $\mathrm{f} \mathrm{x} \mathrm{b}$ & Presentase (\%) \\
\hline 5 & 105 & 525 & 13.46 \\
\hline 4 & 361 & 1444 & 46.28 \\
\hline 3 & 110 & 330 & 14.10 \\
\hline 2 & 139 & 278 & 17.82 \\
\hline 1 & 65 & 65 & 8.33 \\
\hline Jumlah & 780 & 2642 & 100 \\
\hline Skor & $=\sum(\mathrm{f} \mathrm{x} \mathrm{b)} \mathrm{/n}$ & \multicolumn{2}{|c|}{3.39} \\
\hline Klasifikasi & $=$ & \multicolumn{2}{|c|}{ Baik } \\
\hline
\end{tabular}

Pada skor kategori variabel Motivasi menunjukan angka 3,39. Nilai ini berada pada rentang 3,41 hingga 4,20, hal ini mengklasifikasikan kategori baik pada variabel tersebut. Dengan demikian dapat disimpulkan bahwa Motivasi sudah baik berdasarkan persepsi 39 orang tersebut. Untuk mengetahui gambaran mengenai persepsi 39 Responden terhadap variabel Kompensasi $\left(\mathrm{X}_{3}\right)$ digunakan analisis deskriptif secara statistik. 
Tabel 4. Distribusi Frekuensi variabel kompensasi $\left(\mathrm{X}_{3}\right)$

\begin{tabular}{|c|c|c|c|}
\hline Alternatif jawaban & Frekuensi (f) & $\mathrm{f} \mathrm{x} \mathrm{b}$ & Presentase (\%) \\
\hline 5 & 57 & 285 & 9.74 \\
\hline 4 & 320 & 1280 & 54.70 \\
\hline 3 & 97 & 291 & 16.58 \\
\hline 2 & 103 & 206 & 17.61 \\
\hline 1 & 8 & 8 & 1.37 \\
\hline Jumlah & 585 & 2070 & 100 \\
\hline Skor & $=\sum(\mathrm{f} \times \mathrm{b}) / \mathrm{n}$ & \multicolumn{2}{|c|}{3.54} \\
\hline Klasifikasi & $=$ & \multicolumn{2}{|c}{ Baik } \\
\hline
\end{tabular}

Pada skor kategori variabel Kompensasi menunjukan angka 3,54. Nilai ini berada pada rentang 3,41 hingga 4,20, hal ini mengklasifikasikan kategori baik pada variabel tersebut. Dengan demikian dapat disimpulkan bahwa Kompensasi sudah baik berdasarkan persepsi 39 orang tersebut. Untuk mengetahui gambaran mengenai persepsi 39 Responden terhadap variabel Kinerja Dosen (Y) digunakan analisis deskriptif secara statistik.

Tabel. 5 Distribusi Frekuensi variabel kinerja dosen $(\mathrm{Y})$

\begin{tabular}{|c|c|c|c|}
\hline Alternatif jawaban & Frekuensi (f) & $\mathrm{f} \mathrm{x} \mathrm{b}$ & Presentase (\%) \\
\hline 5 & 135 & 675 & 13.85 \\
\hline 4 & 474 & 1896 & 48.62 \\
\hline 3 & 169 & 507 & 17.33 \\
\hline 2 & 156 & 312 & 16.00 \\
\hline 1 & 41 & 41 & 4.21 \\
\hline Jumlah & 975 & 3431 & 100 \\
\hline Skor & $=\sum(\mathrm{f} \mathrm{x} \mathrm{b)/n}$ & \multicolumn{2}{|c|}{3.52} \\
\hline Klasifikasi & $=$ & \multicolumn{2}{|c|}{ Baik } \\
\hline
\end{tabular}

Pada skor kategori variabel Kinerja Dosen menunjukan angka 3,52. Nilai ini berada pada rentang 3,41 hingga 4,20, hal ini mengklasifikasikan kategori baik pada variabel tersebut. Dengan demikian dapat disimpulkan bahwa Kinerja Dosen sudah baik berdasarkan persepsi 39 orang tersebut. Untuk mengukur atau memperoleh penjelasan mengenai tingkat keeratan hubungan antara variabel X (Kepemimpinan, Motivasi, dan Kompensasi) terhadap variabel Y (kinerja Dosen) perlu dilakukan analisis korelasi. Dalam penelitian ini pengukuran tingkat keeratan hubungan antar variabel menggunakan rumus analisis koefisien korelasi Product Moment Pearson. Berdasarkan perhitungan dengan menggunakan rumus tersebut korelasi antara variabel X (Kepemimpinan, Motivasi, dan Kompensasi), variabel Y (Kinerja Dosen), didapat koefisien korelasi yang sebagai berikut (Tabel 6).

Koefisien korelasi antara variabel kepemimpinan $\left(\mathrm{X}_{1}\right)$ dengan variabel kinerja Dosen adalah sebesar 0,785. Menurut kriteria Guilford, besarnya koefisien ini berarti terdapat hubungan yang kuat antara kepemimpinan $\left(\mathrm{X}_{1}\right)$ dengan variabel kinerja dosen. Nilai signifikansi sebesar 0,000 lebih kecil jika dibandingkan dengan $\alpha=5 \%$ sebesar 0,05 . Dengan demikian terdapat hubungan yang signifikan antara Kepemimpinan $\left(\mathrm{X}_{1}\right)$ dengan Kinerja Dosen $(\mathrm{Y})$.

Koefisien korelasi antara variabel Motivasi $\left(\mathrm{X}_{2}\right)$ dengan variabel kinerja Dosen adalah sebesar 0,737. Menurut kriteria Guilford, besarnya koefisien ini berarti terdapat hubungan yang kuat antara Motivasi $\left(\mathrm{X}_{2}\right)$ dengan variabel kinerja dosen. Nilai signifikansi sebesar 0,000 lebih kecil jika dibandingkan dengan $\alpha=5 \%$ sebesar 0,05 . Dengan demikian terdapat hubungan yang signifikan antara Motivasi $\left(\mathrm{X}_{2}\right)$ dengan Kinerja Dosen $(\mathrm{Y})$. 
Koefisien korelasi antara variabel Motivasi $\left(\mathrm{X}_{3}\right)$ dengan variabel kinerja Dosen adalah sebesar 0,631. Menurut kriteria Guilford, besarnya koefisien ini berarti terdapat hubungan yang kuat antara Motivasi $\left(\mathrm{X}_{3}\right)$ dengan variabel kinerja dosen. Nilai signifikansi sebesar 0,000 lebih kecil jika dibandingkan dengan $\alpha=5 \%$ sebesar 0,05 . Dengan demikian terdapat hubungan yang signifikan antara Motivasi $\left(\mathrm{X}_{3}\right)$ dengan Kinerja Dosen $(\mathrm{Y})$. Dengan demikian dapat disimpulkan bahwa masing-masing variabel independen yaitu Kepemimpinan, Motivasi, dan Kompensasi memiliki hubungan linier secara positif terhadap variabel dependen yaitu Kinerja Dosen

Tabel 6. Korelasional antar variable

\begin{tabular}{|c|c|c|c|c|c|}
\hline \multicolumn{6}{|c|}{ Correlations } \\
\hline & & $\begin{array}{l}\text { Kepemim } \\
\text { pinan (X1) }\end{array}$ & Motivasi (X2) & $\begin{array}{c}\text { Kompensasi } \\
\text { (X3) }\end{array}$ & $\begin{array}{c}\text { Kinerja } \\
\text { Dosen }(Y)\end{array}$ \\
\hline \multirow[t]{3}{*}{ Kepemimpinan (X1) } & Pearson Correlation & 1 & $.747^{\star \star}$ & $.497^{\star \star}$ & $.785^{\star \star}$ \\
\hline & Sig. (2-tailed) & & .000 & .001 & .000 \\
\hline & $\mathrm{N}$ & 39 & 39 & 39 & 39 \\
\hline \multirow[t]{3}{*}{ Motivasi (X2) } & Pearson Correlation & $.747^{* \star}$ & 1 & $.344^{*}$ & $.737^{\star \star}$ \\
\hline & Sig. (2-tailed) & .000 & & .032 & .000 \\
\hline & $\mathrm{N}$ & 39 & 39 & 39 & 39 \\
\hline \multirow[t]{3}{*}{ Kompensasi (X3) } & Pearson Correlation & $.497^{\star \star}$ & $.344^{*}$ & 1 & $.631^{\star \star}$ \\
\hline & Sig. (2-tailed) & .001 & .032 & & .000 \\
\hline & $\mathrm{N}$ & 39 & 39 & 39 & 39 \\
\hline \multirow[t]{3}{*}{ Kinerja Dosen (Y) } & Pearson Correlation & $.785^{\star \star}$ & $.737^{* *}$ & $.631^{* *}$ & 1 \\
\hline & Sig. (2-tailed) & .000 & .000 & .000 & \\
\hline & $\mathrm{N}$ & 39 & 39 & 39 & 39 \\
\hline
\end{tabular}

\footnotetext{
${ }^{* *}$. Correlation is significant at the 0.01 level (2-tailed).

*. Correlation is significant at the 0.05 level (2-tailed).
}

Tabel 7. Hasil Uji Statistik t

\section{Coefficients $^{a}$}

\begin{tabular}{|c|c|c|c|c|c|c|}
\hline \multirow{2}{*}{\multicolumn{2}{|c|}{ Model }} & \multicolumn{2}{|c|}{$\begin{array}{l}\text { Unstandardized } \\
\text { Coefficients }\end{array}$} & \multirow{2}{*}{$\begin{array}{c}\text { Standardized } \\
\text { Coefficients }\end{array}$} & \multirow[b]{2}{*}{$t$} & \multirow[b]{2}{*}{ Sig. } \\
\hline & & $\mathrm{B}$ & Std. Error & & & \\
\hline \multirow[t]{4}{*}{1} & (Constant) & -29.180 & 11.057 & & -2.639 & .012 \\
\hline & Kepemimpinan (X1) & .617 & .243 & .349 & 2.539 & .016 \\
\hline & Motivasi (X2) & .542 & .190 & .362 & 2.855 & .007 \\
\hline & Kompensasi (X3) & .674 & .197 & .333 & 3.424 & .002 \\
\hline
\end{tabular}

a. Dependent Variable: Kineria Dosen (Y)

Untuk mengetahui pengaruh kepemimpinan terhadap kinerja Dosen, maka dilakukan dengan pengujian statistik $t$. Pengujian statistik $t$ bertujuan untuk melihat seberapa jauh pengaruh satu variabel independen terhadap variabel dependen dengan menganggap variabel independen lainnya konstan. Jadi pengujian statistik $t$ ini digunakan untuk mengetahui apakah terdapat pengaruh secara parsial antara pengaruh yang signifikan secara statistik antara variabel Kepemimpinan $\left(\mathrm{X}_{1}\right)$ terhadap Kinerja Dosen (Y). Dalam pengujian ini jika $t$ hitung $>t$ tabel atau signifikansi $t$ hitung $<\alpha$, maka ini berarti terdapat pengaruh yang signifikan secara statistik antara variabel independen tersebut terhadap variabel dependen. Nilai t tabel untuk jumlah sampel sebanyak 39 responden tingkat $\alpha=0,05$ adalah sebesar 2,026.

Hipotesis yang diajukan untuk penelitian ini, yaitu Ho: Tidak terdapat pengaruh yang signifikan secara statistik antara variabel Kepemimpinan $\left(\mathrm{X}_{1}\right)$ terhadap Kinerja Dosen (Y); $\mathbf{H}_{\mathbf{1}}$ : Terdapat pengaruh yang signifikan secara statistik antara variabel Kepemimpinan $\left(\mathrm{X}_{1}\right)$ terhadap Kinerja Dosen (Y). 
Hasil pengujian signifikansi parameter individual (uji statistik t) pada tabel output SPSS dapat dilihat pada tabel Coefficientsa seperti yang ditampilkan pada tabel 7. Dari tabel tersebut dapat dilihat bahwa $t$ hitung 2,539 untuk variabel Kepemimpinan lebih besar dari nilai tabel yaitu sebesar 2,026. Nilai signifikansi t hitung variabel independen pun sebesar 0,000 lebih kecil dari nilai tingkat $\alpha$ yang ditetapkan 0,05. Jadi dapat disimpulkan bahwa terdapat pengaruh yang signifikan secara statistik antara variabel Kepemimpinan $\left(\mathrm{X}_{1}\right)$ terhadap Kinerja Dosen $(\mathrm{Y})$.

Tabel 8. Pengaruh Kepemimpinan $\left(\mathrm{X}_{1}\right)$ terhadap Kinerja Dosen $(\mathrm{Y})$

\begin{tabular}{|c|c|c|c|}
\hline Variabel & Pengaruh & r2 & $\%$ \\
\hline \multirow{4}{*}{$\mathrm{X}_{1}$} & Pengaruh langsung ke Y & 0,122 & 12,18 \\
\cline { 2 - 4 } & Pengaruh tidak langsung melalui $\mathrm{X}_{2} \mathrm{ke} \mathrm{Y}$ & 0,094 & 9,44 \\
\cline { 2 - 4 } & Pengaruh tidak langsung melalui $\mathrm{X}_{3}$ ke Y & 0,057 & 5,77 \\
\cline { 2 - 4 } & Total & 0,274 & 27,39 \\
\hline
\end{tabular}

Pengaruh secara langsung antara Kepemimpinan $\left(\mathrm{X}_{1}\right)$ terhadap Kinerja Dosen (Y) sebesar 12,18\%. Pengaruh tidak langsung antara Kepemimpinan $\left(\mathrm{X}_{1}\right)$ terhadap Kinerja Dosen (Y) melalui Motivasi $\left(\mathrm{X}_{2}\right)$ sebesar 9,44\%. Pengaruh tidak langsung antara Kepemimpinan $\left(\mathrm{X}_{1}\right)$ terhadap Kinerja Dosen (Y) melalui Kompensasi $\left(\mathrm{X}_{3}\right)$ sebesar 5,77\%. Total pengaruh Kepemimpinan $\left(\mathrm{X}_{1}\right)$ baik secara langsung maupun tidak langsung terhadap kinerja $=12,18 \%+9,44 \%+5,77 \%=$ $27,39 \%$.

Untuk mengetahui pengaruh Motivasi terhadap kinerja Dosen, maka dilakukan dengan pengujian statistik t. Pengujian statistik $\mathrm{t}$ bertujuan untuk melihat seberapa jauh pengaruh satu variabel independen terhadap variabel dependen dengan menganggap variabel independen lainnya konstan. Jadi pengujian statistik $\mathrm{t}$ ini digunakan untuk mengetahui apakah terdapat pengaruh secara parsial antara pengaruh yang signifikan secara statistik antara variabel Motivasi $\left(\mathrm{X}_{2}\right)$ terhadap Kinerja Dosen (Y). Dalam pengujian ini jika $t$ hitung $>$ t tabel atau signifikansi $\mathrm{t}$ hitung $<\alpha$, maka ini berarti terdapat pengaruh yang signifikan secara statistik antara variabel independen tersebut terhadap variabel dependen. Nilai t tabel untuk jumlah sampel sebanyak 39 responden tingkat $\alpha=0,05$ adalah sebesar 2,026.

Hipotesis yang diajukan untuk penelitian ini, yaitu Ho: Tidak terdapat pengaruh yang signifikan secara statistik antara variabel Motivasi $\left(\mathrm{X}_{2}\right)$ terhadap Kinerja Dosen $(\mathrm{Y}) ; \mathbf{H}_{1}$ : Terdapat pengaruh yang signifikan secara statistik antara variabel Motivasi $\left(\mathrm{X}_{2}\right)$ terhadap Kinerja Dosen (Y).

Tabel 9. Hasil Uji Statistik t

Coefficients $^{\mathrm{a}}$

\begin{tabular}{|c|c|c|c|c|c|c|}
\hline \multirow{2}{*}{\multicolumn{2}{|c|}{ Model }} & \multicolumn{2}{|c|}{$\begin{array}{c}\text { Unstandardized } \\
\text { Coefficients }\end{array}$} & \multirow{2}{*}{$\begin{array}{c}\begin{array}{c}\text { Standardized } \\
\text { Coefficients }\end{array} \\
\text { Beta }\end{array}$} & \multirow[b]{2}{*}{$\mathrm{t}$} & \multirow[b]{2}{*}{ Sig. } \\
\hline & & $\mathrm{B}$ & Std. Error & & & \\
\hline \multirow[t]{4}{*}{1} & (Constant) & -29.180 & 11.057 & & -2.639 & .012 \\
\hline & Kepemimpinan (X1) & .617 & .243 & .349 & 2.539 & .016 \\
\hline & Motivasi (X2) & .542 & .190 & .362 & 2.855 & .007 \\
\hline & Kompensasi (X3) & .674 & .197 & .333 & 3.424 & .002 \\
\hline
\end{tabular}

a. Dependent Variable: Kinerja Dosen (Y)

Hasil pengujian signifikansi parameter individual (uji statistik t) pada tabel output SPSS dapat dilihat pada tabel Coefficients ${ }^{\mathrm{a}}$ seperti yang ditampilkan pada tabel 9. Dari tabel tersebut dapat dilihat bahwa $\mathrm{t}$ hitung 2,855 untuk variabel Motivasi lebih besar dari nilai tabel yaitu sebesar 2,026. Nilai signifikansi t hitung variabel independen pun sebesar 0,000 lebih kecil dari nilai tingkat $\alpha$ yang ditetapkan 0,05. Jadi dapat disimpulkan bahwa terdapat pengaruh yang signifikan secara statistik antara variabel Motivasi $\left(\mathrm{X}_{2}\right)$ terhadap Kinerja Dosen (Y). 
Tabel 10. Pengaruh motivasi $\left(\mathrm{X}_{2}\right)$ terhadap kinerja dosen $(\mathrm{Y})$

\begin{tabular}{|c|c|c|c|}
\hline Variabel & Pengaruh & $\mathrm{r} 2$ & $\%$ \\
\hline \multirow{4}{*}{$\mathrm{X}_{2}$} & Pengaruh langsung ke Y & 0,131 & 13,10 \\
\cline { 2 - 4 } & Pengaruh tidak langsung melalui X $\mathrm{X}_{1} \mathrm{ke} \mathrm{Y}$ & 0,094 & 9,44 \\
\cline { 2 - 4 } & Pengaruh tidak langsung melalui $\mathrm{X}_{3}$ ke Y & 0.041 & 4.15 \\
\cline { 2 - 4 } & Total & 0,267 & 26,69 \\
\hline
\end{tabular}

Pengaruh secara langsung antara Motivasi $\left(\mathrm{X}_{2}\right)$ terhadap Kinerja Dosen (Y) sebesar 13,10\%. Pengaruh tidak langsung antara Motivasi $\left(\mathrm{X}_{2}\right)$ terhadap Kinerja Dosen (Y) melalui Kepemimpinan ( $\left.\mathrm{X}_{1}\right)$ sebesar 9,44\%. Pengaruh tidak langsung antara Motivasi $\left(\mathrm{X}_{2}\right)$ terhadap Kinerja Dosen (Y) melalui Kompensasi $\left(\mathrm{X}_{3}\right)$ sebesar $4,15 \%$. Total pengaruh Motivasi $\left(\mathrm{X}_{2}\right)$ baik secara langsung maupun tidak langsung terhadap kinerja $=$ $13,10 \%+9,44 \%+4,15 \%=26,69 \%$.

Untuk mengetahui pengaruh Kompensasi terhadap kinerja Dosen, maka dilakukan dengan pengujian statistik $t$. Pengujian statistik $t$ bertujuan untuk melihat seberapa jauh pengaruh satu variabel independen terhadap variabel dependen dengan menganggap variabel independen lainnya konstan. Jadi pengujian statistik $t$ ini digunakan untuk mengetahui apakah terdapat pengaruh secara parsial antara pengaruh yang signifikan secara statistik antara variabel Kompensasi $\left(\mathrm{X}_{3}\right)$ terhadap Kinerja Dosen $(\mathrm{Y})$. Dalam pengujian ini jika $t$ hitung $>t$ tabel atau signifikansi $\mathrm{t}$ hitung $<\alpha$, maka ini berarti terdapat pengaruh yang signifikan secara statistik antara variabel independen tersebut terhadap variabel dependen. Nilai t tabel untuk jumlah sampel sebanyak 39 responden tingkat $\alpha=0,05$ adalah sebesar 2,026 .

Hipotesis yang diajukan untuk penelitian ini, yaitu Ho: Tidak terdapat pengaruh yang signifikan secara statistik antara variabel Kompensasi $\left(\mathrm{X}_{3}\right)$ terhadap Kinerja Dosen (Y); $\mathbf{H}_{\mathbf{1}}$ : Terdapat pengaruh yang signifikan secara statistik antara variabel Kompensasi $\left(\mathrm{X}_{3}\right)$ terhadap Kinerja Dosen $(\mathrm{Y})$.

Tabel 11. Hasil Uji Statistik t

Coefficients $^{a}$

\begin{tabular}{|c|c|c|c|c|c|c|}
\hline \multirow{2}{*}{\multicolumn{2}{|c|}{ Model }} & \multicolumn{2}{|c|}{$\begin{array}{c}\text { Unstandardized } \\
\text { Coefficients }\end{array}$} & \multirow{2}{*}{$\begin{array}{c}\begin{array}{c}\text { Standardized } \\
\text { Coefficients }\end{array} \\
\text { Beta }\end{array}$} & \multirow[b]{2}{*}{$t$} & \multirow[b]{2}{*}{ Sig. } \\
\hline & & $\mathrm{B}$ & Std. Error & & & \\
\hline \multirow[t]{4}{*}{1} & (Constant) & -29.180 & 11.057 & & -2.639 & .012 \\
\hline & Kepemimpinan (X1) & .617 & .243 & .349 & 2.539 & .016 \\
\hline & Motivasi (X2) & .542 & .190 & .362 & 2.855 & .007 \\
\hline & Kompensasi (X3) & .674 & .197 & .333 & 3.424 & .002 \\
\hline
\end{tabular}

a. Dependent Variable: Kinerja Dosen $(Y)$

Hasil pengujian signifikansi parameter individual (uji statistik t) pada tabel output SPSS dapat dilihat pada tabel Coefficients ${ }^{\mathrm{a}}$ seperti yang ditampilkan pada tabel 11. Dari tabel tersebut dapat dilihat bahwa $\mathrm{t}$ hitung 3,424 untuk variabel Kompensasi lebih besar dari nilai tabel yaitu sebesar 2,026. Nilai

signifikansi t hitung variabel independen pun sebesar 0,000 lebih kecil dari nilai tingkat $\alpha$ yang ditetapkan 0,05 . Jadi dapat disimpulkan bahwa terdapat pengaruh yang signifikan secara statistik antara variabel Kompensasi $\left(\mathrm{X}_{3}\right)$ terhadap Kinerja Dosen $(\mathrm{Y})$.

Tabel 12. Pengaruh Kompensasi $\left(\mathrm{X}_{3}\right)$ terhadap Kinerja Dosen $(\mathrm{Y})$

\begin{tabular}{|c|c|c|c|}
\hline Variabel & Pengaruh & r2 & $\%$ \\
\hline \multirow{4}{*}{$\mathrm{X}_{3}$} & Pengaruh langsung ke Y & 0,111 & 11,11 \\
\cline { 2 - 4 } & Pengaruh tidak langsung melalui $\mathrm{X}_{1} \mathrm{ke} \mathrm{Y}$ & 0,058 & 5,77 \\
\cline { 2 - 4 } & Pengaruh tidak langsung melalui $\mathrm{X}_{2} \mathrm{ke} \mathrm{Y}$ & 0.041 & 4.15 \\
\cline { 2 - 4 } & Total & 0,210 & 21,03 \\
\hline
\end{tabular}


Pengaruh secara langsung antara Kompensasi $\left(\mathrm{X}_{3}\right)$ terhadap Kinerja Dosen $(\mathrm{Y})$ sebesar 11,11\%. Pengaruh tidak langsung antara Kompensasi $\left(\mathrm{X}_{3}\right)$ terhadap Kinerja Dosen (Y) melalui Kepemimpinan $\left(\mathrm{X}_{1}\right)$ sebesar $5,77 \%$. Pengaruh tidak langsung antara Kompensasi $\left(\mathrm{X}_{3}\right)$ terhadap Kinerja Dosen $(\mathrm{Y})$ melalui Kompensasi $\left(\mathrm{X}_{2}\right)$ sebesar 4,15\%. Total pengaruh Kompensasi $\left(\mathrm{X}_{3}\right)$ baik secara langsung maupun tidak langsung terhadap kinerja $=11,11 \%+5,77 \%+4,15 \%=21,03 \%$.

Untuk mengetahui pengaruh antara Kepemimpinan, Motivasi dan Kompensasi Terhadap Kinerja Dosen, maka dilakukan dengan pengujian Uji statistik $\mathrm{F}$, dilakukan untuk mengetahui apakah semua variabel independen yang dimasukkan dalam model mempunyai pengaruh secara bersama-sama atau simultan terhadap variabel dependen. Uji
Statistik F ini merupakan pengujian yang diperlukan dalam menguji hipotesis yang diajukan dalam penelitian ini. Hasil uji ini pada output SPSS dapat dilihat pada tabel ANOVA seperti yang ditampilkan pada tabel 13 .

Hipotesis yang diajukan untuk penelitian ini, yaitu Ho: Tidak terdapat pengaruh yang signifikan secara statistik antara variabel Kepemimpinan $\left(\mathrm{X}_{1}\right)$, Motivasi $\left(\mathrm{X}_{2}\right)$ dan Kompensasi $\left(\mathrm{X}_{3}\right)$ terhadap Kinerja Dosen (Y); $\mathbf{H}_{1}$ : Terdapat pengaruh yang signifikan secara statistik antara variabel Kepemimpinan $\left(\mathrm{X}_{1}\right)$, Motivasi $\left(\mathrm{X}_{2}\right)$ dan Kompensasi $\left(\mathrm{X}_{3}\right)$ terhadap Kinerja Dosen ( $\mathrm{Y}$ ) atau minimal 1 terdapat pengaruh yang signifikan. Kriteria pengujian, yaitu Ho ditolak apabila $\mathrm{F}$ hitung $<F$ tabel atau SignifikansiF hitung $>\alpha ; \mathbf{H}_{1}$ diterima apabila $\mathrm{F}$ hitung $>\mathrm{F}$ tabel atau Signifikansi $\mathrm{F}$ hitung $<\alpha$.

Tabel 13. Hasil Uji Statistik F

ANOVA

\begin{tabular}{|c|c|c|c|c|c|c|}
\hline Model & & $\begin{array}{l}\text { Sum of } \\
\text { Squares }\end{array}$ & $d f$ & Mean Square & $\mathrm{F}$ & Sig. \\
\hline \multirow[t]{3}{*}{1} & Regression & 6479.010 & 3 & 2159.670 & 35.195 & $.000^{\mathrm{a}}$ \\
\hline & Residual & 2147.711 & 35 & 61.363 & & \\
\hline & Total & 8626.720 & 38 & & & \\
\hline
\end{tabular}

a. Predictors: (Constant), Kompensasi (X3), Motivasi (X2), Kepemimpinan (X1)

b. Dependent Variable: Kinerja Dosen $(\mathrm{Y})$

F tabel untuk jumlah sampel 39 dengan 3 variabel independen dan tingkat $\alpha=0,05$ adalah 2,852. Dari tabel 13 dapat dilihat nilai $F$ hitung sebesar 35,195 jauh lebih besar dari $\mathrm{F}$ Tabel yang besarnya 2,852. Nilai Signifikansi F Hitung diperoleh 0,000 yang lebih kecil dari tingkat $\alpha$ yang ditetapkan sebesar 0,05. Dari kedua hal tersebut, maka berdasarkan kriteria pengujian diperoleh kesimpulan bahwa Ho ditolak dan $\mathrm{H}_{1}$ diterima. Jadi terdapat pengaruh yang signifikan secara simultan antara variabel Kepemimpinan $\left(\mathrm{X}_{1}\right)$, Motivasi $\left(\mathrm{X}_{2}\right)$ dan Kompensasi $\left(\mathrm{X}_{3}\right)$ terhadap Kinerja Dosen (Y). kemampuan model path dalam menerangkan variasi variabel dependen. Besaran R Square digunakan untuk mengukur goodness of fits garis regresi. Tetapi ada kelemahan penggunaan besaran $\mathrm{R}$ Square, setiap tambahan satu variabel independen maka nilai $\mathrm{R}$ Square pasti meningkat tidak peduli apakah variabel tersebut berpengaruh secara signifikan terhadap variabel dependen. Oleh karena itu model path linier berganda sebaiknya menggunakan adjusted $R$ square karena disesuaikan dengan jumlah variabel independen yang digunakan dalam penelitian.

Perhitungan koefisien determinasi dilakukan untuk mengukur berapa jauh

Tabel 14. Hasil Pengujian Koefisien Determinasi

Model Summary

\begin{tabular}{|l|r|r|r|r|r|}
\hline Model & $\mathrm{R}$ & R Square & $\begin{array}{c}\text { Adjusted } \\
\text { R Square }\end{array}$ & $\begin{array}{c}\text { Std. Error of } \\
\text { the Estimate }\end{array}$ & $\begin{array}{c}\text { Durbin- } \\
\text { Watson }\end{array}$ \\
\hline 1 & $.867^{\mathrm{a}}$ & .751 & .730 & 7.83346 & 1.892 \\
\hline
\end{tabular}

a. Predictors: (Constant), Kompensasi (X3), Motivasi (X2), Kepemimpinan (X1)

b. Dependent Variable: Kinerja Dosen $(Y)$ 
Tabel 14. merupakan hasil dari pengujian koefisien determinasi. Dari tabel tersebut dapat dilihat bahwa nilai $R$ Square adalah 0,751 dan nilai Adjusted $R$ Square adalah 0,730. Dengan menggunakan nilai adjusted $R$ Square, dapat disimpulkan bahwa $73,0 \%$ variabel Kinerja Dosen (Y) dapat diterangkan oleh variabel Kepemimpinan $\left(\mathrm{X}_{1}\right)$, Motivasi $\left(\mathrm{X}_{2}\right)$ dan Kompensasi $\left(\mathrm{X}_{3}\right)$ yang bersangkutan. Sedangkan sisanya sebesar $27,0 \%$ diterangkan oleh variabel lain yang tidak diteliti dalam penelitian ini.

Untuk memperoleh persamaan analisis jalur, maka diperlukan tabel Coefficients ${ }^{\mathrm{a}}$ yang diperoleh dari output SPSS seperti yang ditampilkan pada Tabel 11. Dari tabel tersebut maka diperoleh nilai parameter konstanta dan nilai parameter penduga untuk melengkapi model path yang sudah dirumuskan sebelumnya. Persamaan path linear berganda (model regresi) yang terbentuk dalam penelitian ini adalah sebagai berikut:

$$
Y=0,349 X_{1}+0,362 X_{2}+0,333 X_{3}+e
$$

Keterangan: $\mathrm{Y}=$ Kinerja Dosen, $\mathrm{X}_{1}=$ Kepemimpinan, $\quad \mathrm{X}_{2}=$ Motivasi, $\quad \mathrm{X}_{3}=$ Kompensasi, E= Faktor error/disturbance.

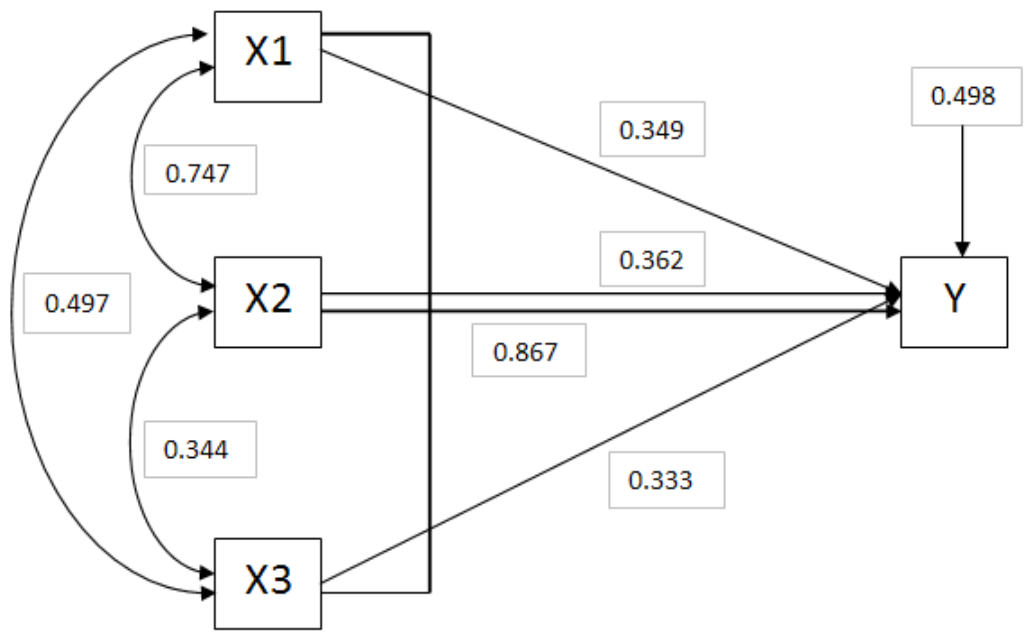

Gambar 3. Analisa Jalur

Nilai koefisien path Kepemimpinan $\left(\mathrm{X}_{1}\right)$ sebesar 0,349, berarti setiap penambahan satu skor variabel Kepemimpinan akan meningkatkan Kinerja Dosen sebesar 0,349 dengan asumsi skor variabel independen lain tetap. Selanjutnya nilai koefisien path Motivasi $\left(\mathrm{X}_{2}\right)$ sebesar 0,362 , berarti setiap penambahan satu skor variabel Motivasi akan meningkatkan Kinerja Dosen sebesar 0,362 dengan asumsi skor variabel independen lain tetap. Selanjutnya nilai koefisien path Kompensasi $\left(X_{3}\right)$ sebesar 0,333 , berarti setiap penambahan satu skor variabel Kompensasi akan meningkatkan Kinerja Dosen sebesar 0,333 dengan asumsi skor variabel independen lain tetap. Besarnya koefisien path yang bernilai positif menunjukkan bahwa semakin baik kepemimpinan, motivasi dan Kompensasi maka kinerja dosen pun akan semakin baik. Terlihat bahwa Koefisien path untuk Motivasi bernilai lebih besar dari koefisien pada Kepemimpinan dan Kompensasi. Dengan demikian disimpulkan bahwa dari ketiga variabel, variabel Motivasi lebih dominan dalam meningkatkan kinerja dosen.

Temuan penelitian menunjukkan bahwa terdapat pengaruh yang signifikan variabel kepemimpinan $\left(\mathrm{X}_{1}\right)$ terhadap variabel kinerja dosen (Y) sebesar 27,39\% dengan koefisien korelasi sebesar 0,785 yang menunjukkan adanya hubungan positif yang kuat. Sesuai dengan penelitian kinerja dosen oleh Nursyamsi mengatakan bahwa kepemimpinan merupakan salah satu dari sekian banyak faktor yang memengaruhi kinerja individu (Nursyamsi, 2012). Jadi hipotesis "terdapat pengaruh yang signifikan variabel kepemimpinan terhadap kinerja dosen" dalam penelitian ini mendapatkan dukungan dari realitas. Kepemimpinan sebagai salah satu faktor yang memengaruhi kinerja dosen di STT dalam hal ini berperan dalam memengaruhi dosen ke arah pencapaian 
tujuan organisasi yang akan tercapai jika setiap dosen memiliki kinerja yang tinggi. Sesuai dengan hasil penelitian yang dilakukan oleh Fauzan bahwa kepemimpinan mempengaruhi dosen dalam pekerjaannya untuk mencapai visi yang ditetapkan (Fauzan, 2014). Oleh karena itu manajemen pengembangan dosen sebagai salah satu komponen penting di perguruan tinggi yang berperan dalam rangka memperbaiki kinerja dosen akan berfungsi secara optimal jika didukung oleh perilaku kepemimpinan yang mampu mendorong dosen untuk bekerja mencapai tujuan pendidikan tinggi yang tercantum dalam PP No. 60 Tahun 1999. Perilaku kepemimpinan yang dapat mempengaruhi kinerja dosen dalam penelitian ini adalah kepemimpinan yang mampu mempengaruhi dosen untuk melaksanakan tugas. Kepemimpinan seperti ini ditandai dengan terjalinnya hubungan yang baik antara pimpinan dengan anggota, adanya kepercayaan kepada pemimpin, rasa hormat anggota kepada pimpinan, ketersediaan prosedur dalam melaksanakan tugas, dan kekuatan posisi pimpinan dalam mengambil kebijakan.

Temuan penelitian menunjukkan bahwa terdapat pengaruh yang signifikan variabel motivasi $\left(\mathrm{X}_{2}\right)$ terhadap variabel kinerja dosen (Y) sebesar 26,69\% dengan koefisien korelasi sebesar 0,737 yang menunjukkan adanya hubungan positif yang kuat. Motivasi yang memiliki pengaruh terhadap kinerja dosen dalam penelitian ini ditunjukkan dengan sikap antusiame dan pesistensi dalam melaksanakan kegiatan, yang ditandai dengan ketekunan mengerjakan tugas, ulet dalam menghadapi masalah, menunjukkan minat, mampu bekerja secara mandiri, menyukai tantangan dan memiliki keyakinan untuk berhasil. Secara umum, temuan penelitian ini sesuai dengan hasil penelitian Pramudyo bahwa motivasi sebagai salah satu faktor yang berinteraksi dengan kinerja di samping kemampuan (Pramudyo, 2010) artinya motivasi seseorang akan berpengaruh terhadap prestasinya (Ulya \& Irawati, 2016) dengan memberikan dorongan yang kuat kepada pencapaian tujuan (Suciani \& Rozali, 2014) yang dilakukan melalui usaha yang konsisten dari individu kepada pencapaian tujuan (Basuki, 2015). Jadi hipotesis "terdapat pengaruh yang signifikan variabel motivasi terhadap kinerja dosen" mendapatkan dukungan dari realitas.

Timbulnya keinginan yang kuat dari dosen untuk mewujudkan apa yang mereka cita-citakan, bisa muncul karena ada kebutuhan, kebutuhan adalah suatu kekurangan. Teori pemenuhan kebutuhan (Need Fullfillment Theory) mengemukakan bahwa tujuan dari pemenuhan kebutuhan itu adalah untuk memperoleh kepuasan, dengan memiliki keinginan yang lebih besar maka peluang untuk meningkatnya kepuasan juga lebih besar meskipun peluang untuk kecewa juga lebih besar. Teori pengharapan yang dikemukakan oleh Vroom mengemukakan bahwa motivasi adalah hasil perpaduan valensi dengan harapan. Munculnya keinginan yang kuat dari dosen-dosen di STT untuk mewujudkan apa yang dicita-citakan, terjadi karena mereka melihat kemungkinan keberhasilan (harapan). Akibatnya peluang untuk memperoleh kekecewaan dapat diperkecil jika dosen mampu melihat peluang keberhasilannya dengan cara mengurangi keinginan (valensi). Pentingnya peranan motivasi dalam mewujudkan kinerja dosen tercantum dalam UU No. 14 Tahun 2005 Pasal 7 Ayat 1 bagian (a) dan (b) mengatakan bahwa prinsip pekerjaan dosen sebagai tenaga profesional perlu didasari atas prinsip panggilan jiwa dan komitmen (Indonesia, 2005).

Temuan penelitian menunjukkan bahwa terdapat pengaruh yang signifikan variabel kompensasi $\left(\mathrm{X}_{3}\right)$ terhadap variabel kinerja dosen (Y) sebesar 21,03\% dengan koefisien korelasi sebesar 0,631 yang menunjukkan adanya hubungan positif yang kuat. Hasil penelitian terhadap variabel kinerja dosen menunjukkan bahwa terdapat 5 orang dosen $(12.8 \%)$ yang menunjukkan kinerja yang tinggi, dari 5 orang dosen yang menunjukkan kinerja tinggi ini, 4 diantaranya berpendapat bahwa mereka memperoleh kompensasi yang tinggi, sementara 1 orang lainnya berpendapat bahwa kompensasi yang diperolehnya sedang Sesuai dengan apa yang dikemukakan oleh Hakim bahwa gaji merupakan salah satu faktor motivasi yang memengaruhi kinerja dosen (Hakim, 2011) dan penelitian Posuma yang mengatakan bahwa kompensasi yang diberikan sesuai kinerja akan mampu meningkatkan 
kinerja pegawai (Posuma, 2013). Jadi hipotesis "terdapat pengaruh yang signifikan variabel kompensasi terhadap kinerja dosen" mendapatkan dukungan dari realitas.

Menurut teori motivasi, salah satu alasan yang mendorong manusia bekerja adalah karena adanya kebutuhan, kompensasi berperan penting dalam memenuhi kebutuhan manusia. Kompesansi sebagai bentuk insentif memiliki hubungan yang erat dengan kinerja dosen (Manik \& Syafrina, 2018) sehingga bisa dikatakan bahwa kinerja merupakan salah satu fungsi dari motivasi (Trisnaningsih, 2011). Di sini bisa dilihat bahwa kompensasi erat kaitannya dengan kebutuhan, dimana kinerja menjadi jembatan yang menghubungan antara kebutuhan dengan kompensasi. Kompensasi timbul atau setidaknya sudah diperhitungkan (disepakati) sebelum seseorang bekerja tapi mungkin baru diperoleh setelah orang menyelesaikan pekerjaannya, akibatnya kompensasi yang diperoleh akan memengaruhi tingkat kinerja individu. Menurut teori keseimbangan (equity theory) dan teori perbedaan (discperancy theory), kepuasan diperoleh dengan menghitung selisih antara pengorbanan dengan pendapatan, akibatnya individu akan menyesuaikan tingkat kinerjanya sesuai dengan kompensasi yang hendak diterimanya. Dapat dijelaskan bagaimana keadilan yang berasal dari teori ekuitas memengaruhi kinerja individu, ia menunjukkan bahwa ketika orang merasakan ketidakadilan mereka berusaha untuk memulihkan keadilan.

Hasil penelitian menunjukkan bahwa terdapat pengaruh simultan yang signifikan variabel kepemimpinan $\left(\mathrm{X}_{1}\right)$, variabel motivasi $\left(\mathrm{X}_{2}\right)$ dan variabel kompensasi $\left(\mathrm{X}_{3}\right)$ terhadap kinerja dosen (Y) sebesar 73\% secara bersamasama. Hal ini membuktikan bahwa sebagian daripada faktor-faktor internal dan eksternal yang memengaruhi kinerja dosen dalam penelitian ini tidak terjadi secara kebetulan tapi secara sistematis. Jadi hipotesis "terdapat pengaruh yang signifikan variabel kepemimpinan $\left(\mathrm{X}_{1}\right)$, variabel motivasi $\left(\mathrm{X}_{2}\right)$ dan varaibel kompensasi $\left(\mathrm{X}_{3}\right)$ terhadap variabel kinerja dosen (Y) secara bersama-sama" terbukti secara empirik mendapatkan dukungan dari realitas.
Temuan penelitian menunjukkan, jika dilihat dari pengaruh secara bersama-sama melalui persamaan path, motivasi memberikan pengaruh yang paling dominan $(0,362)$ diikuti kepemimpinan (0.349) baru kemudian kompensasi $(0,333)$ tapi jika dihitung berdasarkan pengaruh secara parsial, variabel kepemimpinan mempunyai pengaruh paling besar $(27,39 \%)$ diikuti oleh motivasi $(26,69 \%)$ dan kompensasi (21,03\%). Hasil penelitian terhadap kinerja dosen yang dipengaruhi oleh variabel kepemimpinan, motivasi dan kompensasi dalam penelitian ini menunjukkan bahwa 5 orang dosen (12.8\%) menunjukkan kinerja yang tinggi, 29 orang dosen $(74.4 \%)$ menunjukkan kinerja yang sedang, dan 5 orang dosen (12.8\%) menunjukkan kinerja yang rendah. Jadi dapat disimpulkan bahwa secara parsial, pengaruh kepemimpinan lebih dominan namun secara simultan pengaruh motivasi lebih dominan, hal ini bisa terjadi karena pengaruh tidak langsung yang ditimbulkan kepemimpinan lebih besar dibandingkan motivasi dan kompensasi. Temuan ini menguatkan teori motivasi yang dikemukakan Herzberg yang memasukkan kepemimpinan dan kompensasi sebagai faktor pemelihara, di mana pengaruhnya lebih kecil jika dibandingkan dengan faktor pemotivasi seperti keinginan untuk maju (Herzberg, Mausner, \& Snyderman, 1959).

\section{PENUTUP}

Secara umum penelitian ini telah sesuai dengan tujuan yang diharapkan dalam penelitian ini, yaitu untuk menganalisa pengaruh kepemimpinan, motivasi dan kompensasi terhadap kinerja dosen di STT Kharisma, STT Bandung dan STT INTI. Berdasarkan permasalahan dan tujuan yang dipaparkan dalam penelitian ini, kemudian dikaitkan dengan temuan penelitian dan pembahasannya, maka secara garis besar dapat ditarik simpulan bahwa terdapat pengaruh yang signifikan variabel kepemimpinan $\left(\mathrm{X}_{1}\right)$ terhadap variabel kinerja dosen (Y) sebesar $27,39 \%$ dengan koefisien korelasi sebesar 0,785 yang menunjukkan adanya hubungan positif yang kuat artinya dengan semakin baik persepsi dosen terhadap kepemimpinan di STT maka kinerjanya pun akan semakin baik pula. Nilai koefisien path Kepemimpinan $\left(\mathrm{X}_{1}\right)$ 
sebesar 0,349, berarti setiap penambahan satu skor variabel Kepemimpinan akan meningkatkan Kinerja Dosen sebesar 0,349 dengan asumsi skor variabel independen lain tetap.Terdapat pengaruh yang signifikan variabel motivasi $\left(\mathrm{X}_{2}\right)$ terhadap variabel kinerja dosen (Y) sebesar 26,69\% dengan koefisien korelasi sebesar 0,737 yang menunjukkan adanya hubungan positif yang kuat artinya dengan semakin baik persepsi dosen terhadap motivasi yang ada dalam dirinya maka kinerjanya pun akan semakin baik pula. Nilai koefisien path Motivasi $\left(\mathrm{X}_{2}\right)$ sebesar 0,362, berarti setiap penambahan satu skor variabel Motivasi akan meningkatkan Kinerja Dosen sebesar 0,362 dengan asumsi skor variabel independen lain tetap.Terdapat pengaruh yang signifikan variabel kompensasi $\left(\mathrm{X}_{3}\right)$ terhadap variabel kinerja dosen (Y) sebesar 21,03\% dengan koefisien korelasi sebesar 0,631 yang menunjukkan adanya hubungan positif yang kuat artinya dengan semakin baik persepsi dosen terhadap kompensasi yang diterimanya maka kinerjanya pun akan semakin baik pula. Nilai koefisien path Kompensasi $\left(\mathrm{X}_{3}\right)$ sebesar 0,333 , berarti setiap penambahan satu skor variabel Kompensasi akan meningkatkan Kinerja Dosen sebesar 0,333 dengan asumsi skor variabel independen lain tetap. Terdapat pengaruh simultan yang signifikan variabel kepemimpinan $\left(\mathrm{X}_{1}\right)$, variabel motivasi $\left(\mathrm{X}_{2}\right)$ dan variabel kompensasi $\left(\mathrm{X}_{3}\right)$ terhadap kinerja dosen (Y) sebesar $73 \%$ artinya dengan semakin baik kepemimpinan, motivasi dan kompensasi yang dipersepsikan dosen di STT maka kinerjanya pun akan semakin baik. Di antara ketiga variabel di atas, motivasi paling dominan dalam meningkatkan kinerja dosen di STT. Di samping variabel kepemimpinan, motivasi dan kompensasi masih terdapat variabel lain yang berpengaruh terhadap kinerja dosen di STT.

Ketua STT perlu memberikan kesempatan kepada dosen untuk menyampaikan keinginan-keinginan dan harapan mereka kepada institusi. Ketua dalam hal ini perlu menyediakan waktu khusus untuk membicarakan hal tersebut bersama-sama dengan dosen, dengan demikian dapat terjalin hubungan baik antara ketua dengan dosen yang akan memperkuat posisi kepemimpinan ketua. Untuk meningkatkan motivasi dosen maka ketua perlu memberikan penghargaan kepada dosen atas usaha yang mereka lakukan dalam melaksanakan tugas-tugasnya. Penghargaan hendaknya diberikan sesegera mungkin setelah tugas diselesaikan dan disampaikan secara tulus oleh ketua. Dalam menetapkan kompensasi kepada dosen, hendaknya dilakukan dengan adil. Caranya dengan melakukan analisa pekerjaan untuk menetapkan nilai dari setiap pekerjaan sehingga tercapai keadilan internal. Kemudian melakukan survei gaji untuk pekerjaan yang sama di tempat lain untuk menjamin keadilan eksternal. Dengan terpenuhinya prinsip keadilan dalam penetapan kompensasi maka hal ini akan dapat membantu dalam memelihara kinerja dosen. Untuk meningkatkan kinerja dosen di STT, perlu disusun sistem penilaian kinerja dosen. Dimulai dengan mengidentifikasi aspek-aspek yang akan dinilai dari pekerjaan dosen, menetapkan standar untuk setiap aspek pekerjaan yang dinilai tersebut untuk kemudian dilakukan pengukuran, hasilnya diinformasikan kepada dosen. Selanjutnya dilakukan upaya-upaya perbaikan dan serangkaian keputusan untuk memelihara dan meningkatkan kinerja dosen. Kepada peneliti selanjutnya diharapkan untuk meneliti variabelvariabel lain yang belum diteliti dalam penelitian ini (kemampuan, latar belakang, demografi, intelektual, persepsi, sikap, kepribadian, pendidikan, sumber daya, struktur dan desain pekerjaan) sehingga dapat ditemukan hasil penelitian yang lebih optimal.

\section{DAFTAR PUSTAKA}

Awaluddin, M. (2016). Pengaruh budaya organisasi, kepuasan dan lingkungan kerja terhadap kinerja dosen uin alauddin makassar. ASSETS, 6(1), 116-125.

Basuki, K. H. (2015). Pengaruh Kecerdasan Spiritual dan Motivasi Belajar terhadap Prestasi Belajar Matematika. Formatif: Jurnal Ilmiah Pendidikan MIPA, 5(2), 120-133.

https://doi.org/10.30998/formatif.v5i2.332

Effendi, Y. (2013). Performance Kinerja Dosen di Lingkungan Universitas Riau Kepulauan ditinjau dari Aspek Supervisi Dekan pada tahun Akademik 2012-2013. 
Jurnal Dimensi, 3(1), 1-7.

Fauzan, M. (2014). Peningkatan kinerja dosen berbasis modal sosial dan dukungan organisasional di pts kota semarang. Jurnal Bisnis Dan Ekonomi (JBE), 19(2), 188-203.

Fiedler, F. E. (1967). A Theory of Leadership Effectiveness. New York: Mc.Graw Hill.

Gibson, J. L. (2012). Organization Behavior, Structure, Processes. Fourteenth Edition. New York: McGraw-Hill.

Hakim, L. (2011). PENGARUH MOTIVASI KERJA TERHADAP KINERJA DOSEN STIE. Jurnal Ilmu Manajemen Dan Akuntansi Terapan, 2(2), 1-10.

Herzberg, F., Mausner, B., \& Snyderman, B. B. (1959). The Motivation to Work. Second edition (2nd ed.). New York: John Wiley \& Sons.

Indonesia. (2003). Undang-Undang Republik Indonesia Nomor 20 Tahun 2003 Tentang Sistem Pendidikan Nasional.

Indonesia. (2005). Undang-Undang Republik Indonesia Nomor 14 Tahun 2005 Tentang Guru dan Dosen.

Jahan, S., \& Jespersen, E. (2016). Human Development Report 2016 Human Development for Everyone.

Kementerian Agama. (2018). RENCANA STRATEGIS TAHUN 2015-2019 Direktorat Jenderal Bimbingan Masyarakat Kristen Kementerian Agama $R I$

Manik, S., \& Syafrina, N. (2018). PENGARUH KOMPETENSI TERHADAP KINERJA DOSEN. Jurnal Ilmiah Ekonomi Dan Bisnis, 11(1), 1-6.

Moekijat. (1992). Administrasi Gaji dan Upah. Bandung: CV Mandar Maju.

Nongkeng, H., Armanu, Troena, E. A., \& Setiawan, M. (2012). Pengaruh Pemberdayaan , Komitmen Organisasional terhadap Kinerja dan Kepuasan Kerja Dosen ( Persepsi Dosen Dipekerjakan PTS Kopertis Wilayah IX Sulawesi di Makassar ). Jurnal Aplikasi Manajemen, 10(September), 575-585.
Nursyamsi, I. (2012). Pengaruh Kepemimpinan, Pemberdayaan, dan Stress Kerja terhadap Komitmen Organisasional serta Dampaknya terhadap Kinerja Dosen. Proceedings of Confrence In Business, Accounting and Management (CBAM), 1(1), 405-423.

Permanasari, R., Setyaningrum, R. M., \& Sundari, S. (2014). MODEL HUBUNGAN KOMPETENSI RELATIONSHIP MODEL BETWEEN COMPETENCE ,. Jurnal Bisnis, Manajemen \& Perbankan, 1(2), 157-174.

Posuma, C. O. (2013). Kompetensi, Kompensasi, dan Kepemimpinan Pengaruhnya terhadap Kinerja Karyawan pada Rumah Sakit Ratumbuysang Manado. Jurnal EMBA, 1(4), 646-656.

Pramudyo, A. (2010). Analisis Faktor-Faktor yang Mempengaruhi Kinerja Dosen Negeri pada Kopertis Wilayah V Yogyakarta. Jurnal JBTI, 1(1), 1-11.

Sardiman, A. (2011). Interaksi \& Motivasi Belajar Mengajar. Jakarta: Rajawali Press.

Shofwa, Y. S. (2013). Pengaruh Motivasi Spiritual dan Kepemimpinan Spiritual Terhadap Kinerja Religius Dosen dan Karyawan STAIN Purwokerto. Jurnal Pro Bisnis, 6(1), 1-19.

Suciani, D., \& Rozali, Y. A. (2014). Hubungan Dukungan Sosial dengan Motivasi Belajar pada Mahasiswa Universitas Esa Unggul. Jurnal Psikologi, 12(2), 43-47.

Trisnaningsih, S. (2011). FAKTOR-FAKTOR YANG MEMPENGARUHI KINERJA DOSEN AKUNTANSI Sri Trisnaningsih UPN “ Veteran " Jawa Timur. Jurnal Akuntansi \& Auditing, 8(1), 83-94.

Ulya, I. F., \& Irawati, R. (2016). Peningkatan Kemampuan Koneksi Matematis Dan Motivasi Belajar Siswa Menggunakan Pendekatan Kontekstual. Pena Ilmiah, l(1), 121-130.

Winardi. (2002). Motivasi dan Pemotivasian dalam Manajemen. Jakarta: PT. Raja Grafindo Persada. 
